\title{
IMPORTANCE OF CHOLINE DURING GROWTH, WITH PARTICULAR REFERENCE TO SYNTHETIC DIETS IN PHENYLKETONURIA
}

\author{
BY \\ K. MARGARET WILSON and BARBARA E. CLAYTON \\ From the Department of Chemical Pathology, The Hospital for Sick Children, \\ Great Ormond Street, London
}

(RECEIVED FOR PUBLICATION JULY 17, 1962)

Moncrieff and Wilkinson (1961) and Brimblecombe, Blainey, Stoneman and -Wood (1961) have described the development of a severe extensive skin eruption in babies fed on the low-phenylalanine food 'minafen' (Trufood Ltd.).

More recently, two further phenylketonuric children have been seen at Great Ormond Street with bizarre rashes. One, a baby, developed a rash similar to that described by Moncrieff and Wilkinson (1961) while receiving minafen. From contacts with other paediatricians it has become apparent that a number of patients have developed this syndrome, and in some instances there has been a fatal outcome. The other, a 3-year-old child, developed the rash while receiving a grossly inadequate diet.

In an attempt to elucidate possible causes of rashes in these children, synthetic low-phenylalanine foods have been fed to rats, and the effect of increasing certain nutritional factors has been studied. It was also possible to make some investigations on the older patient and these indicated the importance of choline, riboflavine and vitamin $\mathrm{E}$.

As a result of the investigations, certain modifications in the synthetic food have been suggested.

\section{Case Report}

D.B. was first treated with a low phenylalanine (Phe) diet when she was $5 \frac{1}{2}$ weeks old and weighed $4 \mathrm{~kg}$. Initially she received minafen (supplemented with 'abidec' (Parke, Davis and Co. Ltd.) and ascorbic acid) only, but after 10 days this was supplemented with double cream and then with double cream and cow's milk for 17 and 13 days respectively. Five days after the diet commenced, her perineum became red and sore, and over the next four weeks her condition gradually deteriorated. The napkin area showed widespread excoriation and was flaming red, she developed red erythematous patches on her knees and on her back, and her ears and the folds of her neck were red and weeping. Local treatment of the rash was ineffective.
She was restless and unhappy and did not gain weight after the first few days on the diet. At the height of the rash, the blood phenylalanine levels may have been lower than normal as no spot was seen on the papers developed by a chromatographic technique then in use, which did not detect less than $3 \mathrm{mg} . / 100 \mathrm{ml}$. plasma. In view of her serious condition she was changed first to 'lofenalac' for 48 hours and then entirely to cow's milk. Three days later the skin lesions were drier and less inflamed and she was much happier. Improvement continued, and after two weeks her skin healed completely. Minafen was then reintroduced into the diet in increasing amounts and there was a tendency for the skin lesions to recur. During the period when minafen was reintroduced the levels of phenylalanine in the plasma varied between 4 and $12 \mathrm{mg} . / 100 \mathrm{ml}$. It was difficult to give sufficient minafen to lower the level of Phe in the blood without a recurrence of the rash, but she was eventually able to go home, when 4 months old, on a diet of $3 \frac{3}{4} \mathrm{oz}$. minafen, $4 \mathrm{oz}$. milk and $2 \mathrm{oz}$. potato.

\section{Material and Methods}

Synthetic Low-phenylalanine Foods. Three commercially available preparations have been investigated: minafen; 'cymogran' (Allen and Hanburys Ltd.); and 'lofenalac' (Mead Johnson Ltd.).

The recommended daily supplements for minafen, which is made primarily for babies, are (1) 10 drops of abidec and (2) $50 \mathrm{mg}$. ascorbic acid. Cymogran is manufactured for older children and the recommended daily supplements are (1) three tablets of 'ketovite' (Paines and Byrnes Ltd.), (2) 10 drops 'adexolin' (Glaxo Laboratories Ltd.), and (3) 60 minims 'cytocon' (Glaxo Laboratories Ltd.). Since minafen and cymogran contain not more than $20 \mathrm{mg}$. and $10 \mathrm{mg}$. of Phe/100 g. respectively, milk and other foods according to the age of the child must be given in just sufficient quantities to supply the necessary amount of Phe for optimum growth of the child.

Lofenalac is a complete food for phenylketonuric babies and older children, except that it contains no ascorbic acid, though the manufacturers recommend giving extra vitamins. The mean Phe content is $80 \mathrm{mg} . / 100 \mathrm{~g}$. 
TABLE 1

DIETARY FACTORS SUPPLIED BY MINAFEN AND SUPPLEMENTS, CYMOGRAN AND SUPPLEMENTS, AND LOFENALAC IN 2-MONTH-OLD BABY OF $4.98 \mathrm{~kg}$.

\begin{tabular}{|c|c|c|c|c|c|c|c|}
\hline & & & & & $\begin{array}{c}\text { Minafen } \\
100 \mathrm{~g} .550 \mathrm{cal} .\end{array}$ & $\begin{array}{c}\text { Lofenalac } \\
125 \mathrm{~g} .562 \mathrm{cal} .\end{array}$ & $\begin{array}{c}\text { Cymogran } \\
100 \mathrm{~g} .\end{array}$ \\
\hline 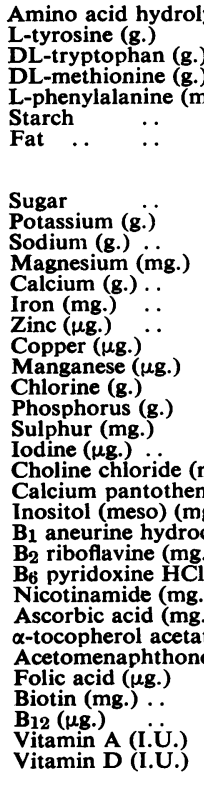 & $\begin{array}{l}\text { lysate (g } \\
\ldots \\
\text { ag.) } \\
\ldots \\
\ldots \\
\ldots \\
\ldots \\
\ldots \\
\ldots \\
\ldots \\
\ldots \\
\ldots \\
\ldots \\
\ldots \\
\text { mg.) } \\
\text { nate (mg } \\
\text { chloride } \\
\text { i (mg.) } \\
\text { or nic } \\
\text { ) DL (r } \\
\text { e (mg.) } \\
\ldots \\
\ldots \\
\ldots \\
\ldots \\
. .\end{array}$ & 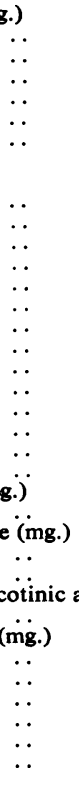 & $\begin{array}{l}\ldots \\
\ldots \\
\ldots \\
\ldots \\
\ldots \\
\\
\ldots \\
\ldots \\
\ldots \\
\ldots \\
\ldots \\
\ldots \\
\ldots \\
\ldots \\
\ldots \\
\ldots \\
\ldots \\
\ldots \\
\ldots \\
\ldots \\
\ldots \\
\ldots \\
\ldots \\
\ldots \\
\ldots \\
\ldots \\
\end{array}$ & 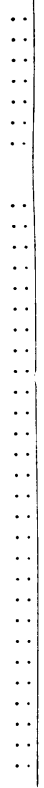 & 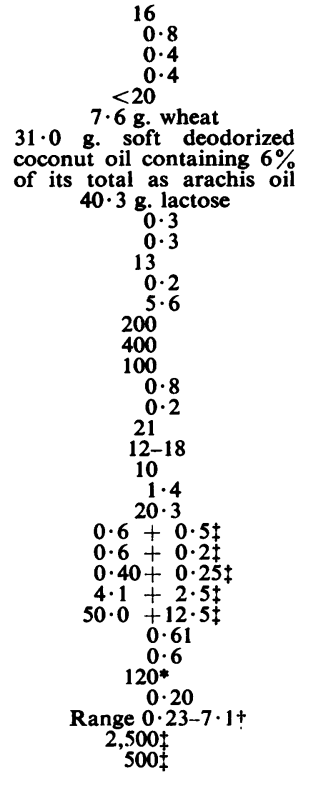 & $\begin{array}{c}25 \\
0 \cdot 5 \\
0 \cdot 5 \\
0 \cdot 9 \\
75-125 \\
11 \cdot 3 \mathrm{~g} . \text { arrowroot } \\
22 \cdot 5 \mathrm{~g} . \text { corn oil } \\
\\
60 \cdot 0 \mathrm{~g} \cdot \text { dextrimaltose } \\
1 \cdot 3 \\
0 \cdot 5 \\
0 \cdot 8 \\
12 \cdot 5 \\
\text { Not known } \\
125 \\
\text { Not known } \\
0 \cdot 7 \\
0 \cdot 6 \\
7 \\
\text { Not known } \\
123 \\
2 \cdot 7 \\
\text { Not known } \\
0 \cdot 3 \\
1 \cdot 7 \\
0 \cdot 53 \\
0 \cdot 7 \\
\text { nil } \\
\text { At least } 7 \cdot 8 \\
\text { nil } \\
44 \\
0 \cdot 03 \\
\text { nil } \\
2,197 \\
352 \\
\end{array}$ & 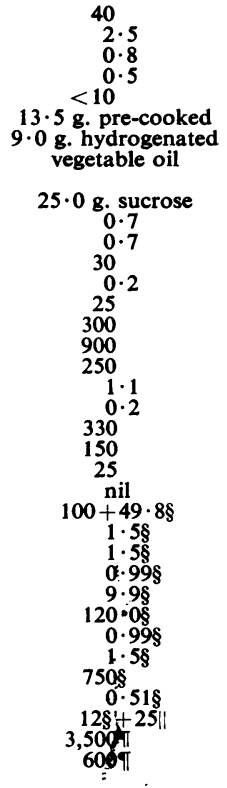 \\
\hline
\end{tabular}

* Determined by direct microbiological assay, and supplied by Ext. Hep. Liq. B.P. 1948.

$\dagger$ From Ext. Hep. Liq. B.P. 1948.

$\ddagger$ Given as abidec; infants up to 1 year of age: $0.3 \mathrm{ml}$. daily.

$\S$ Given as ketovite, 3 tablets/day.

Given as cytacon, $60 \mathrm{minims} / \mathrm{day}$.

II Given as adexolin, 10 drops/day.

TABLE 2

EFFECT OF FEEDING MINAFEN, CYMOGRAN AND LOFENALAC TO RATS

\begin{tabular}{|c|c|c|c|c|c|c|c|c|c|}
\hline Group & $\begin{array}{c}\text { No. } \\
\text { of } \\
\text { Rats }\end{array}$ & Age & $\begin{array}{c}\text { Basic } \\
\text { Diet }\end{array}$ & $\begin{array}{l}\text { Supple- } \\
\text { ments to } \\
\text { Diet }\end{array}$ & $\begin{array}{c}\text { Days } \\
\text { on } \\
\text { Diet }\end{array}$ & $\begin{array}{c}\% \text { Change in } \\
\text { Body Weight } \\
\text { During } \\
\text { Experiment }\end{array}$ & $\begin{array}{c}\text { Weight of Liver } \\
\text { (g.) }\end{array}$ & $\begin{array}{c}\text { Weight of } \\
\text { Right Adrenal } \\
\text { (mg.) }\end{array}$ & $\begin{array}{l}\text { Ratio Right } \\
\text { Adrenal Weight } \\
\text { (mg.)/Body } \\
\text { Weight (g.) }\end{array}$ \\
\hline $\mathbf{a}$ & 6 & Young & Cubes & None & 22 & $\begin{array}{l}+77 \\
\pm 6\end{array}$ & $\begin{array}{r}7 \cdot 4 \\
\pm 0 \cdot 3\end{array}$ & $\begin{aligned} & 27 \cdot 6 \\
\pm & 0 \cdot 5\end{aligned}$ & $\begin{array}{l}0.16 \\
+0.006\end{array}$ \\
\hline b & 6 & Young & $\mathbf{M}$ & None & 22 & $\begin{array}{l}-26 \\
\pm 2\end{array}$ & $\begin{array}{r}3 \cdot 3 \\
\pm 0 \cdot 2\end{array}$ & $\begin{array}{r}16 \cdot 0 \\
\pm \quad 0.2\end{array}$ & $\begin{array}{l}0.22 \\
\pm 0.001\end{array}$ \\
\hline c & 6 & Young & C & None & 22 & $\begin{array}{r}-27 \\
\pm 2\end{array}$ & $\begin{array}{r}2 \cdot 9 \\
\pm 0 \cdot 1\end{array}$ & $\begin{array}{r}12 \cdot 0 \\
\pm \quad 0.4\end{array}$ & $\begin{array}{l}0.17 \\
\pm 0.007\end{array}$ \\
\hline d & 6 & Young & $\mathbf{L}$ & None & 22 & $\begin{array}{l}-20 \\
\pm 1\end{array}$ & $\begin{array}{r}3 \cdot 3 \\
+0 \cdot 1\end{array}$ & $\begin{array}{r}14 \cdot 0 \\
\pm \quad 0 \cdot 2\end{array}$ & $\begin{array}{r}0 \cdot 18 \\
\pm 0 \cdot 01\end{array}$ \\
\hline e & 6 & Mature & Cubes & None & 22 & $\begin{array}{l}+18 \\
\pm 2\end{array}$ & $\begin{array}{r}7 \cdot 9 \\
+0 \cdot 4\end{array}$ & $\begin{array}{r}29 \cdot 4 \\
\pm \quad 1 \cdot 2\end{array}$ & $\begin{array}{l}0.14 \\
\pm 0.005\end{array}$ \\
\hline f & 6 & Mature & $\mathbf{M}$ & None & 22 & $\begin{array}{l}-18 \\
\pm 2\end{array}$ & $\begin{array}{r}6 \cdot 1 \\
\pm 0 \cdot 2\end{array}$ & $\begin{array}{r}20 \cdot 0 \\
\pm \quad 1 \cdot 5\end{array}$ & $\begin{array}{l}0.14 \\
\pm 0.007\end{array}$ \\
\hline $\mathbf{g}$ & 6 & Young & $\mathbf{M}$ & Phe* & 10 & $\begin{array}{l}-9 \\
\pm 1\end{array}$ & $\begin{array}{r}4 \cdot 3 \\
\pm 0 \cdot 3\end{array}$ & $\begin{array}{r}15.0 \\
\pm \quad 0.6\end{array}$ & $\begin{aligned} & 0.20 \\
\pm & 0.004\end{aligned}$ \\
\hline $\mathbf{h}$ & 6 & Young & $\mathbf{L}$ & Phe* & 10 & $\begin{array}{l}+39 \\
\pm 4\end{array}$ & $\begin{array}{r}6 \cdot 6 \\
\pm 0 \cdot 5\end{array}$ & $\begin{array}{r}16 \cdot 3 \\
\pm \quad 0 \cdot 5\end{array}$ & $\begin{array}{l}0.15 \\
\pm 0.007\end{array}$ \\
\hline
\end{tabular}

* L-Phe added $/ 100 \mathrm{~g}$. food $=1 \mathrm{~g}$. Average calorie intake/rat/day was 40 and 60 for groups $\mathrm{g}$ and $\mathrm{h}$ respectively.

All results are means \pm S.E. $\quad \mathbf{M}=$ minafen; $\mathbf{C}=$ cymogran; $\mathbf{L}=$ lofenalac. 
The amino acids in minafen and cymogran are supplied by an acid hydrolysate of casein, whereas an enzymic hydrolysate is used in lofenalac. In minafen the fat is a mixture of $94 \%$ soft deodorized coconut oil and $6 \%$ arachis oil. A partially hydrogenated vegetable fat is used in cymogran and corn oil is used in lofenalac.

Table 1 lists the dietary intakes of a number of factors by an infant weighing $4.98 \mathrm{~kg}$. when fed on minafen and the recommended supplements, or on lofenalac. Similar information is given for $100 \mathrm{~g}$. cymogran fed with three tablets of ketovite.

Henceforth in this paper, the terms minafen and cymogran refer to these foods plus their recommended supplements, so that in the animal experiments minafen and cymogran in fact had the composition shown in Table 1 and not the composition of the original commercial preparations without the supplements advised by the manufacturers.

Lofenalac provides the infant with greater amounts of choline, riboflavine and $\alpha$-tocopherol than are supplied by minafen (Table 1). The differences between lofenalac and cymogran are less.

\section{Animal Experiments}

Female Sprague-Dawley rats obtained from Animal Supplies (London) Ltd. were used in all experiments. Young and mature rats weighed $70-100 \mathrm{~g}$. and $185 \mathrm{~g}$. respectively when experiments were begun. Cubes (Diet 41B, Joseph Rank Ltd.) were used as a control diet. Tap water was available ad lib. Animals were housed in cages with grids so that they could not eat their faeces, and were kept for at least three days before experiments were begun.

For ad lib. feeding, foods and supplements were made into a thick mash with tap water and placed in troughs in the cages. The amount of food eaten each day was determined. For feeding by stomach-tube, synthetic foods and supplements were mixed with tap water to such a consistency that the mixture could be injected down the tube two or three times daily. It was impossible to feed mashed cubes down a tube. In tubefeeding experiments, therefore, control animals received water from the tube and were given a cube mash in the cage.

Since lofenalac contains more Phe than the other two synthetic foods, Phe was added to minafen and cymogran so that the basic concentration in all preparations used was $80 \mathrm{mg} . / 100 \mathrm{~g}$. dry food. The rats were weighed to the nearest $g$. each day except Sundays. At the end of each experiment the animals were killed with ether and examined. The weights of the livers, right adrenal gland and right kidney were determined. The adrenals from Groups a, b, c, d and $\mathrm{g}$ in Experiment 1 were sectioned and stained with haematoxylin and eosin.

Experiment 1: Effect of feeding minafen, cymogran and lofenalac ad lib. to young and mature rats with and without large supplements of phenylalanine. Groups of young and mature rats were fed various diets and these and the results are summarized in Table 2 . On diets lacking supplements of Phe the rats did not gain weight. Young rats receiving minafen (Group b) developed diarrhoea within a few hours of beginning the diet, and the passage of loose, light brown stools continued throughout the experiment. They deteriorated in appearance after two days, their fur became matted and staring and a little was lost over the dorsum of the neck. Their tails became shrunken and dry, and the tails, paws and ears were discoloured by a sticky brownish material. They became apathetic and were shaky when they walked. At autopsy it was observed that the vaginae were closed and the uterine horns were thin in contrast to the open vaginae and greater maturity of the genital tract in the cube-fed controls; no fat was present in the abdominal cavities, the livers were of normal appearance, the adrenal glands were enlarged; when minafen was fed to mature rats (Group $f$ ) the changes were much milder, though slight roughness of the fur and some loose stools occurred after three days, and minimal discoloration and limp appearance of the tails did not appear until they had been on the diet for two weeks. These rats showed mild fatty degeneration of their livers, and the abdominal fat pads, uteri and ovaries were smaller than in the controls. The ratio of the weight of the right adrenal gland in mg. to body weight in $\mathrm{g}$. (A/B) was $0 \cdot 14$ and not significantly different from that of the cube-fed controls. Young rats fed on cymogran (Group c) also showed much milder though similar changes compared with minafen, but they did not have diarrhoea and the A/B was not significantly raised. In contrast to minafen, young rats fed on lofenalac (Group d) showed only slight deterioration of their fur, only slight discoloration of their paws, tails and ears, and they remained lively and free of diarrhoea. The amount of phenylalanine present in lofenalac ( $80 \mathrm{mg} . / 100 \mathrm{~g}$. food) was, of course, insufficient to result in growth of the rats. At autopsy the vaginae were open, genital tracts well developed, and A/B was not significantly increased.

Rats in Group $h$ received an adequate intake of Phe with their lofenalac. They grew well (Fig. 2) and had a lively, healthy appearance. Rats in Group $\mathrm{g}$ also received an adequate intake of $P$ he with their minafen, but they had diarrhoea, failed to grow (Figs. 1 and 2), had staring fur, no abdominal fat pads, significantly increased A/B ( $<<0.01)$ and, indeed, showed little or no improvement compared with those fed minafen without extra Phe.

The quantities of synthetic diets eaten were variable, but on average the quantity of minafen eaten per rat per day, with or without added Phe, was 7-9 and $4 \mathrm{~g}$. respectively, and the intakes of lofenalac alone and lofenalac with extra Phe were 5.0 and 9-13 g. respectively.

Sections of the adrenals from minafen-fed rats (Group b) showed hypertrophy of the zona fasciculata, with intense vacuolation of all the cells of this zone and dilatation of the sinusoids throughout the cortex. The addition of Phe (Group g) did not alter this appearance. The changes with cymogran (Group c) were similar, but much less, and with lofenalac (Group d) the only abnormal finding was slight dilatation of the sinusoids.

It was concluded that lofenalac was a satisfactory food for the young growing rat. Since the intake of 

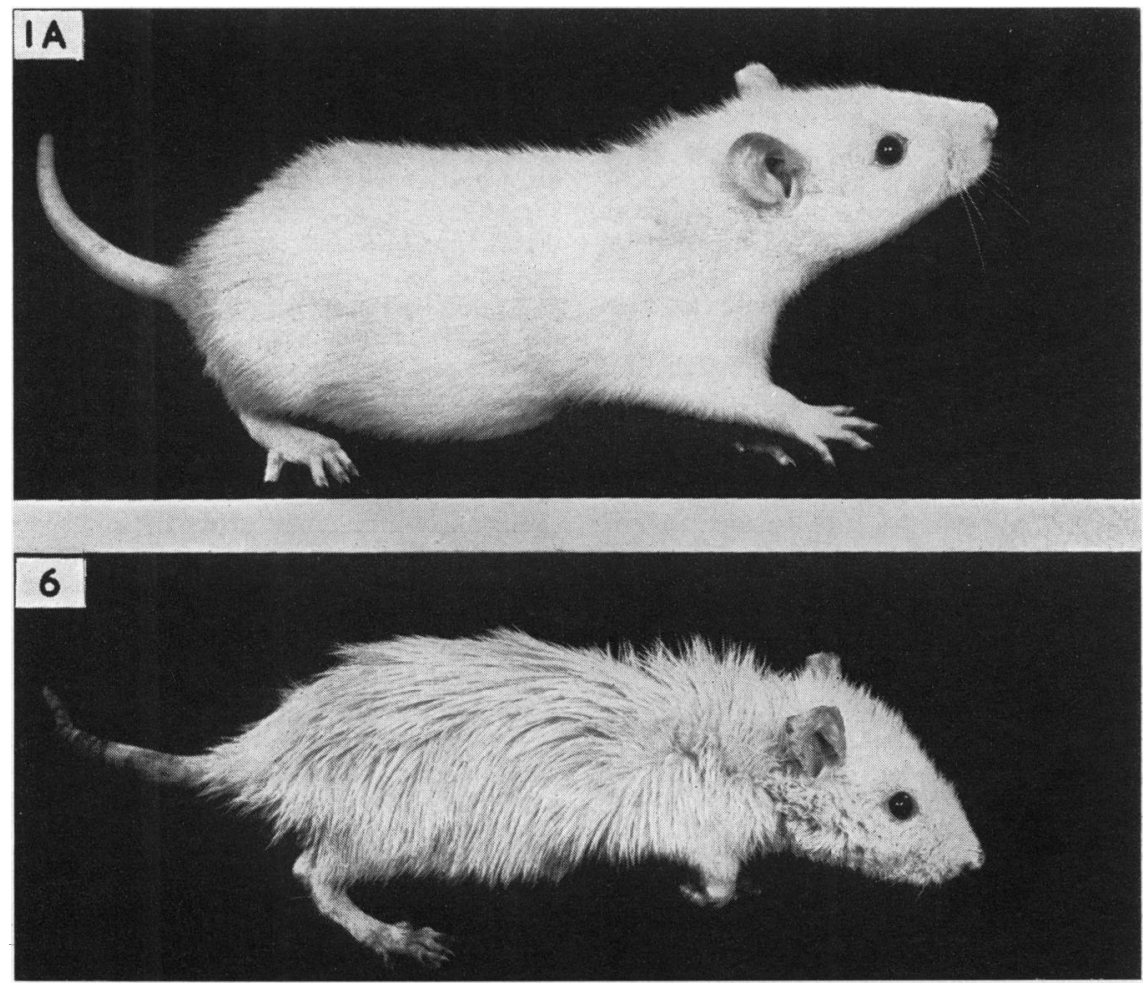

Fig. 1.-1A: rat fed on cubes (Table 2, Group a). 6: rat fed on minafen + phenylalanine (Table 2, Group g).

lofenalac was greater than that of minafen when extra Phe was given, it was necessary to try force-feeding to increase the intake of minafen. These observations are described in Experiment 4. Also, since Mitchell (1927) showed that lactose was not the most satisfactory sugar for young rats, the effect of changing the sugar in minafen was studied in Experiment 5. Mitchell (1927) found, however, that diarrhoea and retardation of growth were not usually prominent until the percentage of lactose in the diet reached $60 \%$.

TABLE 3

EFFECT OF FEEDING MINAFEN TO WHICH ADDITIONAL AMOUNTS OF CERTAIN AMINO ACIDS HAVE BEEN ADDED

\begin{tabular}{|c|c|c|c|c|c|c|c|}
\hline Group & $\begin{array}{l}\text { No. } \\
\text { of } \\
\text { Rats }\end{array}$ & $\begin{array}{c}\text { Supplement } \\
\text { to } \\
\text { Diet* }\end{array}$ & $\begin{array}{c}\text { Days } \\
\text { on } \\
\text { Diet }\end{array}$ & $\begin{array}{c}\text { \% Change in } \\
\text { Body Weight } \\
\text { During Experiment }\end{array}$ & $\begin{array}{l}\text { Weight of } \\
\text { Liver } \\
\text { (g.) }\end{array}$ & $\begin{array}{c}\text { Weight of } \\
\text { Right Adrenal } \\
\text { (mg.) }\end{array}$ & $\begin{array}{l}\text { Ratio Right Adrenal } \\
\text { Weight (mg.)/Body } \\
\text { Weight (g.) } \dagger\end{array}$ \\
\hline a & 7 & None & 23 & $\begin{array}{l}-17 \\
\pm 1\end{array}$ & $\begin{array}{r}3 \cdot 3 \\
\pm 0 \cdot 2\end{array}$ & $\begin{array}{l}17 \cdot 0 \\
\pm 0 \cdot 8\end{array}$ & $\begin{array}{r}0.22 \\
\pm 0.01\end{array}$ \\
\hline b & 7 & Try & 23 & $\begin{array}{l}-27 \\
\pm 2\end{array}$ & $\begin{array}{r}3.9 \\
\pm 0.1\end{array}$ & $\begin{array}{l}16 \cdot 0 \\
\pm 1 \cdot 2\end{array}$ & $\begin{array}{r}0.23 \\
\pm 0.02\end{array}$ \\
\hline c & 7 & Tyr & 23 & $\begin{array}{l}-24 \\
\pm 1\end{array}$ & $\begin{array}{r}3 \cdot 0 \\
\pm 0 \cdot 2\end{array}$ & $\begin{aligned} & 15 \cdot 0 \\
\pm & 2 \cdot 1\end{aligned}$ & $\begin{array}{r}0 \cdot 20 \\
\pm 0.02\end{array}$ \\
\hline d & 7 & Try + Tyr & 10 & $\begin{array}{l}-15 \\
\pm 1\end{array}$ & $\begin{array}{r}3 \cdot 2 \\
\pm 0 \cdot 2\end{array}$ & $\begin{array}{r}13 \cdot 0 \\
\pm \quad 0.5\end{array}$ & $\begin{array}{r}0.21 \\
\pm 0.01\end{array}$ \\
\hline e & 7 & Try + Tyr + Phe & 10 & $\begin{array}{l}-15 \\
\pm 2\end{array}$ & $\begin{array}{r}3.1 \\
\pm 0.1\end{array}$ & $\begin{array}{r}13 \cdot 0 \\
\pm \quad 0.4\end{array}$ & $\begin{array}{c}0.22 \\
\pm 0.008\end{array}$ \\
\hline
\end{tabular}

All results are means \pm S.E.

* Additions to $100 \mathrm{~g}$. minafen: L-Phe $1 \mathrm{~g}$; DL-Try $4 \mathrm{~g}$; L-Tyr $8 \mathrm{~g}$. $\quad$ There were no significant differences between these ratios. 


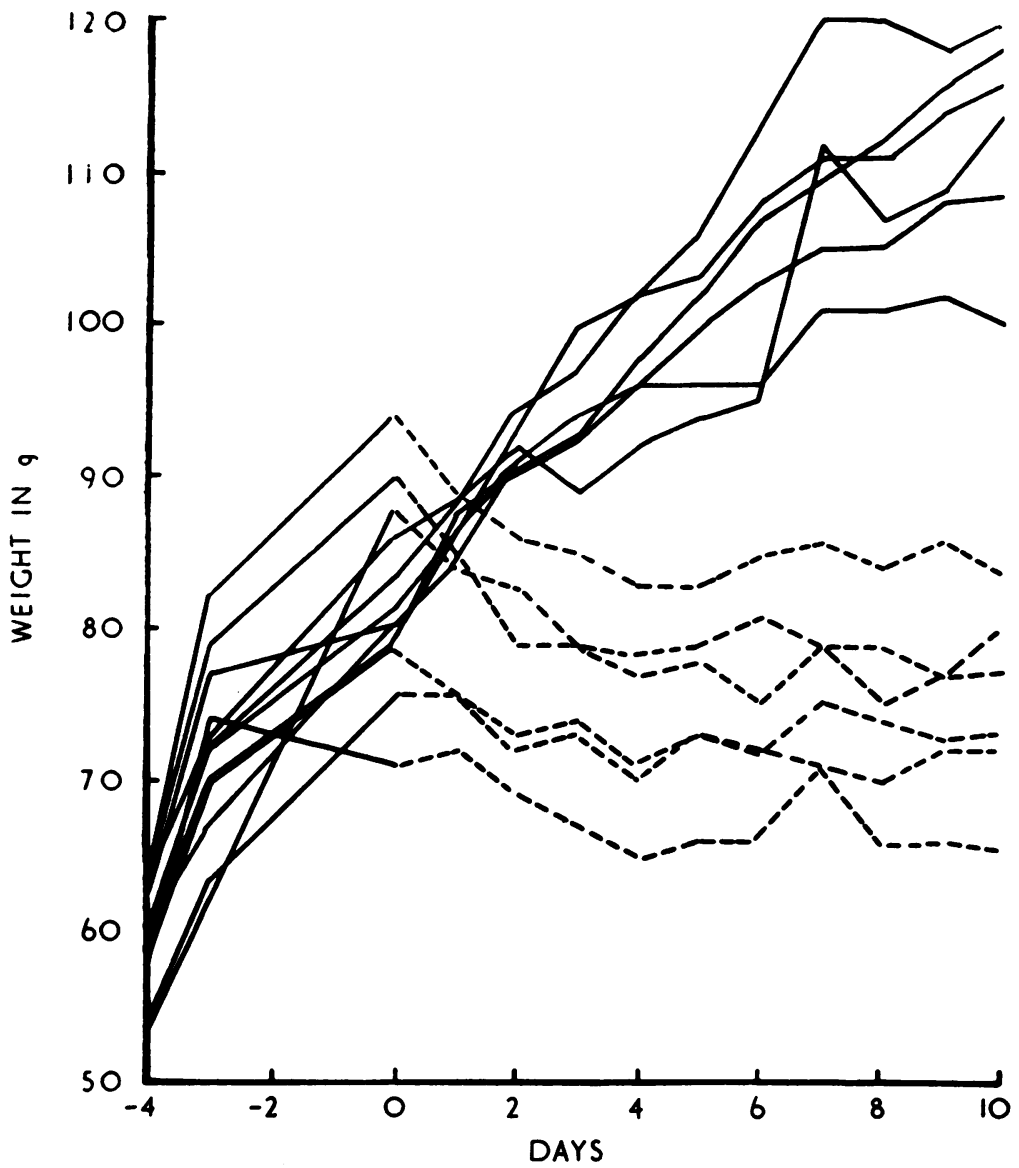

Fig. 2.-Growth curves of immature rats fed on lofenalac and phenylalanine ——_ (Group h, Table 2), or minafen and phenylalanine - - - (Group g, Table 2). Diets began on Day 0.

Experiment 2: Effect of feeding minafen to which additional amounts of amino acids were added. Groups of young rats were fed ad lib. with minafen containing additional amounts of tryptophan (Try), tyrosine (Tyr) and Phe, and the details of the experiment and results are summarized in Table 3 . Groups $\mathrm{a}, \mathrm{b}$ and $\mathrm{c}$ were studied together, and $\mathrm{d}$ and $\mathrm{e}$ later. The latter were killed after 10 days because the rats showed no improvement.

None of the additions produced any effect, all rats looked as though they had been fed on minafen, and it was concluded that minafen was not deficient in Try or Tyr. As in Experiment 1, the addition of Phe did not change the findings caused by feeding minafen alone.

Experiment 3: Effect of feeding minafen with additional amounts of choline, $\alpha$-tocopheryl acetate, calcium pantothenate, riboflavine and folic acid. Groups of young rats were fed ad lib. on minafen to which extra amounts of folic acid $(F)$, choline chloride $(\mathrm{Cho})$, riboflavine $\left(\mathrm{B}_{2}\right)$, $\alpha$-tocopheryl acetate $(E)$, calcium pantothenate $(P)$ and
Phe had been added in various combinations. Details of the experiment and the results are given in Table 4.

Rats receiving a supplement of $\mathbf{P}$, were similar in every way to those receiving minafen only. Rats receiving minafen and Cho or $\mathbf{B}_{2}$ or $\mathbf{F}$ had softer, shinier fur than those fed minafen only, and they were more lively. Their diarrhoea was much reduced, their vaginae were open and the uteri were larger. There were no fat pads and no significant reductions in the A/B ratios, and the livers were healthy. Cho produced a greater effect than $B_{2}$ or $F$.

Of combinations which included Phe (Groups $\mathrm{g}$ to $\mathrm{k}$ inclusive), those fed to Groups $\mathrm{j}$ and $\mathrm{k}$ were best, these groups having normal fur, being very lively and having only slight diarrhoea. The A/B ratios were not significantly reduced, but the vaginae were open, the uteri were well developed and the livers were healthy. Group $\mathbf{k}$, however, had small abdominal fat pads and, unlike Groups $h, i$ and $j$, the weight loss on the diet was significantly less $(p<0.02)$ than that of Group $g$.

The addition of extra amounts of $F$, Cho, $B_{2}, E$ and 
TABLE 4

EXPERIMENT 3: EFFECT OF FEEDING MINAFEN CONTAINING ADDITIONAL AMOUNTS OF CHOLINE, $\alpha$-TOCOPHER YL ACETATE, RIBOFLAVINE AND FOLIC ACID

\begin{tabular}{|c|c|c|c|c|c|c|}
\hline Group & $\begin{array}{l}\text { Basic } \\
\text { Diet }\end{array}$ & $\begin{array}{l}\text { Supplements } \\
\text { to } \\
\text { Diet* }\end{array}$ & $\begin{array}{l}\% \text { Change } \\
\text { in Body } \\
\text { Weight }\end{array}$ & $\begin{array}{l}\text { Weight of } \\
\text { Liver } \\
\text { (g.) }\end{array}$ & $\begin{array}{c}\text { Weight of } \\
\text { Right Adrenal } \\
\text { (mg.) }\end{array}$ & $\begin{array}{c}\text { Ratio Right Adrenal } \\
\text { (mg.)/Body Weight } \\
\text { (g.) }\end{array}$ \\
\hline a & Cubes & None & $\begin{array}{l}+42 \\
\pm 2\end{array}$ & $\begin{array}{r}6 \cdot 7 \\
\pm 0 \cdot 1\end{array}$ & $\begin{array}{r}16 \cdot 0 \\
\pm 0 \cdot 5\end{array}$ & $\begin{array}{l}0 \cdot 14 \\
\pm 0 \cdot 005\end{array}$ \\
\hline b & $\mathbf{M}$ & None & $\begin{array}{r}-17 \\
\pm 2\end{array}$ & $\begin{array}{r}2 \cdot 6 \\
\pm 0 \cdot 2\end{array}$ & $\begin{array}{r}12 \cdot 0 \\
\pm 0 \cdot 6\end{array}$ & $\begin{array}{r}0.19 \\
\pm 0.01\end{array}$ \\
\hline c & $\mathbf{M}$ & $\mathbf{P}$ & $\begin{array}{l}-9 \\
\pm 1\end{array}$ & $\begin{array}{r}3 \cdot 2 \\
\pm 0 \cdot 1\end{array}$ & $\begin{array}{r}13 \cdot 0 \\
\pm 0.5\end{array}$ & $\begin{array}{c}0.20 \\
\pm 0.009\end{array}$ \\
\hline d & $\mathbf{M}$ & $\mathrm{F}$ & $\begin{array}{l}-20 \\
\pm 2\end{array}$ & $\begin{array}{r}2 \cdot 6 \\
\pm 0 \cdot 1\end{array}$ & $\begin{array}{r}12 \cdot 0 \\
\pm 0 \cdot 4\end{array}$ & $\begin{array}{c}0.19 \\
\pm 0.006\end{array}$ \\
\hline $\mathbf{e}$ & $\mathbf{M}$ & $\mathrm{B}_{2}$ & $\begin{array}{l}-17 \\
\pm 1\end{array}$ & $\begin{array}{r}2 \cdot 6 \\
\pm 0.2\end{array}$ & $\begin{array}{r}13 \cdot 0 \\
\pm 0 \cdot 3\end{array}$ & $\begin{array}{l}0 \cdot 19 \\
\pm 0.007\end{array}$ \\
\hline f & $\mathbf{M}$ & Cho & $\begin{array}{l}-11 \\
\pm 3\end{array}$ & $\begin{array}{r}3 \cdot 1 \\
\pm 0 \cdot 2\end{array}$ & $\begin{array}{r}13 \cdot 0 \\
\pm 0 \cdot 8\end{array}$ & $\begin{array}{c}0.18 \\
\pm 0.008\end{array}$ \\
\hline g & $\mathbf{M}$ & Phe & $\begin{array}{l}-11 \\
\pm 2\end{array}$ & $\begin{array}{r}3 \cdot 7 \\
+0.9\end{array}$ & $\begin{array}{r}14 \cdot 0 \\
\pm 0 \cdot 5\end{array}$ & $\begin{array}{c}0.21 \\
\pm 0.009\end{array}$ \\
\hline $\mathrm{h}$ & $\mathbf{M}$ & Phe + E & $\begin{array}{l}-6 \\
+4\end{array}$ & $\begin{array}{r}3 \cdot 4 \\
\pm 0 \cdot 2\end{array}$ & $\begin{array}{r}14 \cdot 0 \\
\pm 0 \cdot 5\end{array}$ & $\begin{aligned} & 0.20 \\
\pm & 0.007\end{aligned}$ \\
\hline i & $\mathbf{M}$ & Phe $+F+B_{2}+$ Cho & $\begin{array}{l}-9 \\
\pm 2\end{array}$ & $\begin{array}{r}3 \cdot 8 \\
\pm 0 \cdot 1\end{array}$ & $\begin{array}{r}13 \cdot 0 \\
\pm 0 \cdot 5\end{array}$ & $\begin{array}{l}0.19 \\
\pm 0.009\end{array}$ \\
\hline $\mathbf{j}$ & $\mathbf{M}$ & $\begin{array}{c}\text { Phe }+F+\mathbf{B}_{2}+ \\
\text { Cho }+E^{-}\end{array}$ & $\begin{array}{l}-5 \\
\pm 5\end{array}$ & $\begin{array}{r}4 \cdot 1 \\
\pm 0 \cdot 1\end{array}$ & $\begin{array}{r}13 \cdot 0 \\
\pm 0 \cdot 8\end{array}$ & $\begin{array}{l}0.18 \\
\pm 0.009\end{array}$ \\
\hline k & $\mathbf{M}$ & $\begin{array}{l}\text { Phe }+ \text { twice amounts } \\
\text { of other supplements } \\
\text { used in Group } j\end{array}$ & $\begin{array}{l}-1 \\
\pm 3\end{array}$ & $\begin{array}{l}3 \cdot 9 \\
\pm 0 \cdot 2\end{array}$ & $\begin{array}{r}13 \cdot 0 \\
\pm 0 \cdot 3\end{array}$ & $\begin{array}{l}0 \cdot 18 \\
\pm 0 \cdot 008\end{array}$ \\
\hline
\end{tabular}

All results are means \pm S.E.

Seven rats/group; eight days on diet.

* Additions to $100 \mathrm{~g}$. minafen: L-Phe $1 \mathrm{~g}$; F $35 \mu \mathrm{g}$.; $\mathrm{B}_{2} 530 \mu \mathrm{g}$; Cho $88 \mathrm{mg}$.; E $5 \cdot 75 \mathrm{mg}$; and P $0 \cdot 8 \mathrm{mg}$. In Group k additions of F, $B_{2}$, Cho, and $\mathrm{E}$ were twice these.

For all groups except $\mathrm{k}$, amounts of $\mathrm{B}_{2}, \mathrm{Cho}, \mathrm{E}$ and $\mathrm{P}$ added bring the total amounts present in the food to the levels in an equal quantity of lofenalac: the amount of $F$ added was that present in lofenalac since Ext. Hep. Liq. B.P., 1948, in minafen contains a variable amount of $\mathbf{F}$.

Phe to minafen therefore made it into a better food, particularly with respect to the fur, tails, paws and ears, but the animals still failed to gain weight and the $A / B$ ratios were not significantly reduced.

Experiment 4: Effect of force-feeding minafen and lofenalac. Preliminary attempts to force-feed minafen showed that it was impossible to give immature rats more than $5 \mathrm{~g}$. per day since their abdomens and intestines became very distended and the animals had severe diarrhoea. The addition of extra Phe did not alter this. With lofenalac and Phe it was possible to give $9 \cdot 6$ g./day.

Using these quantities of food, groups of immature rats were fed as shown in Table 5. Findings similar to those seen with ad lib. feeding were obtained, except that Groups b, c and d had severe abdominal distension. Growth curves are shown in Fig. 3.

The maximum caloric intake of Group $d$ was only 28 per day, compared with the 42 calories given to Group f. It was therefore impossible (since significantly more minafen could not be force-fed than would be eaten ad lib.) to find out whether rats would thrive on the caloric intakes required when a synthetic diet such as minafen was fed.
Experiment 5: Effect of changing the sugar in minafen. Five groups of rats were fed ad lib. for 10 days as shown in Table 6.

The findings in rats in Group b were similar to those observed in rats fed on minafen: they failed to grow (Fig. 4), and the $\mathrm{A} / \mathrm{B}$ ratios were significantly raised ( $p<0.01)$ compared with rats in Group a. In comparison with the listlessness of the rats in Group b, those in Group c were livelier and gained some weight (Fig. 4), and those in Group d were even more active than those in Groups a and e. Rats in Groups c, $d$ and e had no diarrhoea, two, five and seven rats had open vaginae in these groups respectively and all had abdominal fat pads. The A/B ratio, however, was raised in Groups $c$ and d, but not in Group e $(p<0.01)$, compared with Group a.

In addition, four groups of rats were force-fed as follows:

Group $f$ : Minafen made with lactose + Phe.

Group g: Minafen made with dextrimaltose and Phe.

Group $h$ : Minafen made with dextrimaltose + Phe $+\mathbf{F}+\mathbf{B}_{2}+$ Cho $+\mathbf{E}$ (amounts as in Table 5).

Group $i$ : Lofenalac + Phe.

They were equivalent, therefore, to Groups b to e, respectively. 
FIG. 3.-Growth curves of immature rats force-fed on the following: Cubes (42 calories/rat/day, Table 5, Group g), (mean curve); cubes ( 28 calories /rat/day, Table 5, Group a), _ _ _ _ (mean curve); lofenalac and phenylalanine (42 calories/rat/day, Table 5, Group f), —__ (individual curves); minafen and phenylalanine (28 calories /rat/day, Table 5, Group c), - - - (individual curves). Diets began on Day 0.

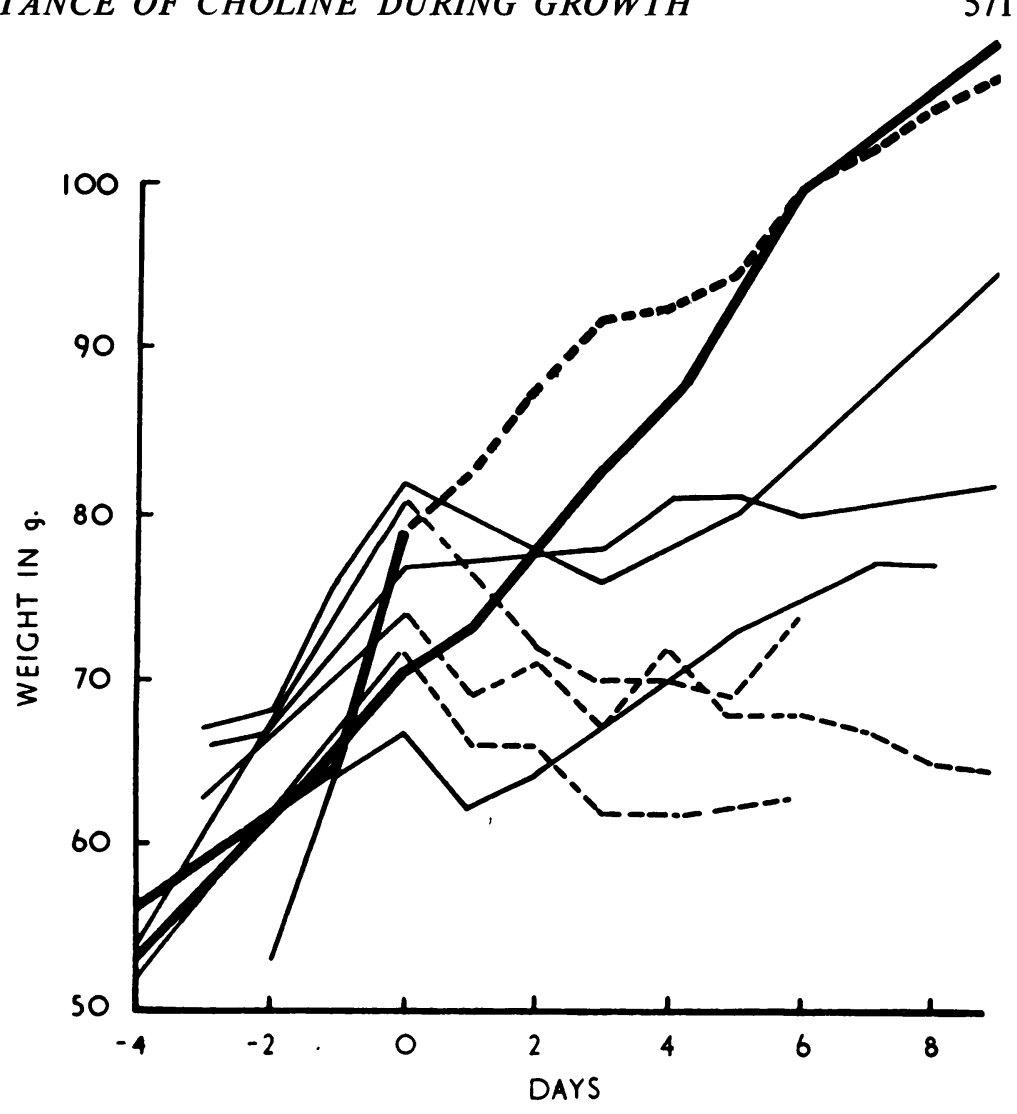

TABLE 5

EXPERIMENT 4: EFFECT OF FORCE-FEEDING MINAFEN AND LOFENALAC Results are for individual rats

\begin{tabular}{|c|c|c|c|c|c|c|c|c|}
\hline Group & Diet & $\begin{array}{c}\text { Supplement } \\
\text { to } \\
\text { Diet* }\end{array}$ & $\begin{array}{l}\text { Approxi- } \\
\text { mate Daily } \\
\text { Caloric } \\
\text { Intake }\end{array}$ & $\begin{array}{l}\text { Days } \\
\text { on } \\
\text { Diet }\end{array}$ & $\begin{array}{c}\% \text { Change in } \\
\text { Body Weight } \\
\text { During } \\
\text { Experiment }\end{array}$ & $\begin{array}{l}\text { Weight of } \\
\text { Liver } \\
\text { (g.) }\end{array}$ & $\begin{array}{l}\text { Weight of } \\
\text { Right Adrenal } \\
\text { (mg.) }\end{array}$ & $\begin{array}{c}\text { Ratio Right } \\
\text { Adrenal Weight } \\
\text { (mg.)/Body Weight } \\
\text { (g.) }\end{array}$ \\
\hline a & Cubes & None & 28 & $\begin{array}{l}9 \\
9 \\
9\end{array}$ & $\begin{array}{l}+25 \\
+36 \\
+29\end{array}$ & $\begin{array}{l}6 \cdot 2 \\
7 \cdot 0 \\
4 \cdot 7\end{array}$ & $\begin{array}{l}16 \cdot 7 \\
14 \cdot 7 \\
12 \cdot 8\end{array}$ & $\begin{array}{l}0 \cdot 16 \\
0 \cdot 14 \\
0 \cdot 14\end{array}$ \\
\hline b & $\mathbf{M}$ & None & 28 & $\begin{array}{l}5 \\
7 \\
8 \\
8\end{array}$ & $\begin{array}{l}-16 \\
-14 \\
-19 \\
-21\end{array}$ & $\begin{array}{l}3 \cdot 4 \\
3 \cdot 7 \\
3 \cdot 5 \\
3 \cdot 5\end{array}$ & $\begin{array}{l}13 \cdot 5 \\
15 \cdot 9 \\
12 \cdot 8 \\
16 \cdot 2\end{array}$ & $\begin{array}{l}0 \cdot 22 \\
0 \cdot 23 \\
0 \cdot 19 \\
0 \cdot 24\end{array}$ \\
\hline c & $\mathbf{M}$ & Phe & 28 & $\begin{array}{r}6 \\
7 \\
10\end{array}$ & $\begin{array}{l}-9 \\
-13 \\
-14\end{array}$ & $\begin{array}{l}5 \cdot 0 \\
4 \cdot 0 \\
3 \cdot 6\end{array}$ & $\begin{array}{l}15 \cdot 7 \\
14 \cdot 5 \\
15 \cdot 2\end{array}$ & $\begin{array}{l}0 \cdot 21 \\
0 \cdot 23 \\
0 \cdot 24\end{array}$ \\
\hline d & $\mathbf{M}$ & $\begin{array}{c}\text { Phe }+\mathbf{F}+ \\
\text { Cho }+ \\
\mathbf{B}_{2}+\mathbf{E}\end{array}$ & 28 & $\begin{array}{l}5 \\
8 \\
8\end{array}$ & $\begin{array}{l}-12 \\
-9 \\
-17\end{array}$ & $\begin{array}{l}3 \cdot 0 \\
3 \cdot 1 \\
4 \cdot 0\end{array}$ & $\begin{array}{l}16 \cdot 9 \\
14 \cdot 8 \\
15 \cdot 5\end{array}$ & $\begin{array}{l}0 \cdot 23 \\
0 \cdot 22 \\
0 \cdot 22\end{array}$ \\
\hline e & $\mathbf{L}$ & None & 28 & $\begin{array}{l}7 \\
8 \\
8\end{array}$ & $\begin{array}{l}-19 \\
-18 \\
-17\end{array}$ & $\begin{array}{l}4 \cdot 0 \\
3 \cdot 7 \\
3 \cdot 4\end{array}$ & $\begin{array}{l}10 \cdot 2 \\
14 \cdot 1 \\
11 \cdot 8\end{array}$ & $\begin{array}{l}0 \cdot 16 \\
0 \cdot 20 \\
0 \cdot 18\end{array}$ \\
\hline $\mathbf{f}$ & $\mathbf{L}$ & Phe & 42 & $\begin{array}{l}7 \\
9 \\
9\end{array}$ & $\begin{array}{l}+15 \\
+15 \\
+3\end{array}$ & $\begin{array}{l}3 \cdot 8 \\
3 \cdot 5 \\
4 \cdot 6\end{array}$ & $\begin{array}{l}16 \cdot 2 \\
13 \cdot 2 \\
19 \cdot 2\end{array}$ & $\begin{array}{l}0.17 \\
0 \cdot 17 \\
0.23\end{array}$ \\
\hline $\mathbf{g}$ & Cubes & None & 42 & $\begin{array}{l}9 \\
9\end{array}$ & $\begin{array}{l}+60 \\
+69\end{array}$ & $\begin{array}{l}6 \cdot 0 \\
6 \cdot 5\end{array}$ & $\begin{array}{l}15 \cdot 3 \\
15 \cdot 4\end{array}$ & $\begin{array}{l}0 \cdot 14 \\
0 \cdot 13\end{array}$ \\
\hline
\end{tabular}

* Additions to 100 g. food: Phe 1 g.; F $35 \mu \mathrm{g}$; Cho $88 \mathrm{mg}$; B $_{2} 530 \mu \mathrm{g}$; E $5 \cdot 75 \mathrm{mg}$. 
TABLE 6

EXPERIMENT 5: EFFECT OF CHANGING THE SUGAR

\begin{tabular}{|c|c|c|c|c|c|c|c|c|}
\hline Group & Diet & Supplement & $\begin{array}{l}\text { Number } \\
\text { of Rats } \\
\text { Per } \\
\text { Group }\end{array}$ & $\begin{array}{l}\text { Daily* } \\
\text { Caloric } \\
\text { Intake }\end{array}$ & $\begin{array}{l}\% \text { Change in } \\
\text { Body Weight } \\
\text { During } \\
\text { Experiment }\end{array}$ & $\begin{array}{l}\text { Weight of } \\
\text { Liver } \\
\text { (g.) }\end{array}$ & $\begin{array}{c}\text { Weight of } \\
\text { Right Adrenal } \\
\text { (mg.) }\end{array}$ & $\begin{array}{c}\text { Ratio Right } \\
\text { Adrenal (mg.)/ } \\
\text { Body Weight (g.) }\end{array}$ \\
\hline $\mathbf{a}$ & Cubes & None & $\begin{array}{l}3 \\
2\end{array}$ & $\begin{array}{l}60 \\
40\end{array}$ & $\begin{array}{r}85 \\
\pm 5 \\
80 \\
\pm 3\end{array}$ & $\begin{array}{r}6 \cdot 7 \\
\pm 0.3 \\
6 \cdot 9 \\
\pm 0 \cdot 7\end{array}$ & $\begin{array}{r}17.4 \\
+0.9 \\
17.4 \\
\pm 2.8\end{array}$ & $\begin{array}{r}0.16 \\
\pm 0.01 \\
0.17 \\
+0.02\end{array}$ \\
\hline $\mathbf{b}$ & M with lactose & Phe & 6 & 28 & $\begin{array}{r}-10 \\
\pm 2\end{array}$ & $\begin{array}{r}3 \cdot 5 \\
\pm 0 \cdot 2\end{array}$ & $\begin{array}{r}13.9 \\
\pm 0.8\end{array}$ & $\begin{array}{r}0.23 \\
+0.02\end{array}$ \\
\hline c & $\begin{array}{c}\text { M with } \\
\text { dextrimaltose } \dagger\end{array}$ & Phe & 6 & 42 & $\begin{array}{l}+8 \\
\pm 3\end{array}$ & $\begin{array}{r}5 \cdot 0 \\
\pm 0 \cdot 5\end{array}$ & $\begin{array}{l}14 \cdot 7 \\
+1 \cdot 1\end{array}$ & $\begin{array}{r}0.20 \\
\pm 0.01\end{array}$ \\
\hline d & $\underset{\text { dextrimaltose }}{\mathbf{M} \text { with }}$ & $\begin{array}{l}\text { Phe }+ \text { F }+ \\
\mathbf{B}_{2}+\text { Cho }+\mathbf{E}\end{array}$ & 6 & 41 & $\begin{array}{r}+13 \\
\pm 2\end{array}$ & $\begin{array}{r}4 \cdot 4 \\
\pm 0 \cdot 3\end{array}$ & $\begin{array}{r}14.6 \\
\pm 0.6\end{array}$ & $\begin{array}{l}0.19 \\
+0.009\end{array}$ \\
\hline $\mathbf{e}$ & $\mathbf{L}$ & Phe & 7 & 51 & $\begin{array}{r}+40 \\
+4\end{array}$ & $\begin{array}{r}5 \cdot 6 \\
\pm 0 \cdot 2\end{array}$ & $\begin{array}{r}13 \cdot 0 \\
\pm 0 \cdot 7\end{array}$ & $\begin{array}{l}0 \cdot 13 \\
\pm 0 \cdot 006\end{array}$ \\
\hline
\end{tabular}

All results are means \pm S.E.

Additions to $100 \mathrm{~g}$. minafen: L-Phe $1 \mathrm{~g}$.; F $35 \mu \mathrm{g}$.; B $_{2} 530 \mu \mathrm{g}$.; Cho $88 \mathrm{mg}$.; E $5 \cdot 75 \mathrm{mg}$.

* Feeding was ad lib. in Groups a to $\mathrm{e}$ inclusive.

$\dagger$ These preparations were specially manufactured by Trufood Ltd.

Unfortunately, even though there was no abdominal distension in Groups $\mathrm{g}, \mathrm{h}$ and $\mathrm{i}$, the calorie intakes were still lower than in those fed ad lib., being 23, 32, 32 and 29 calories per rat per day in Groups $f$ to $i$ respectively. Since contamination of the fur with food did not occur in these force-fed animals, it was easier to assess the integrity of the fur. Those in Group $h$ had excellent smooth coats similar to those fed on cubes, and they had only a trace of brown exudate on their tails and none on their paws. Rats in Groups $g$ and $i$ also had smooth coats, but they were not completely normal and they had a little more brown exudate. Group $f$ had the usual staring fur and exudates seen with minafen. Rats in Groups $h, i$ and $j$ had no diarrhoea, and it was only rare in Group $\mathrm{g}$; as usual, diarrhoea was pronounced in Group f.

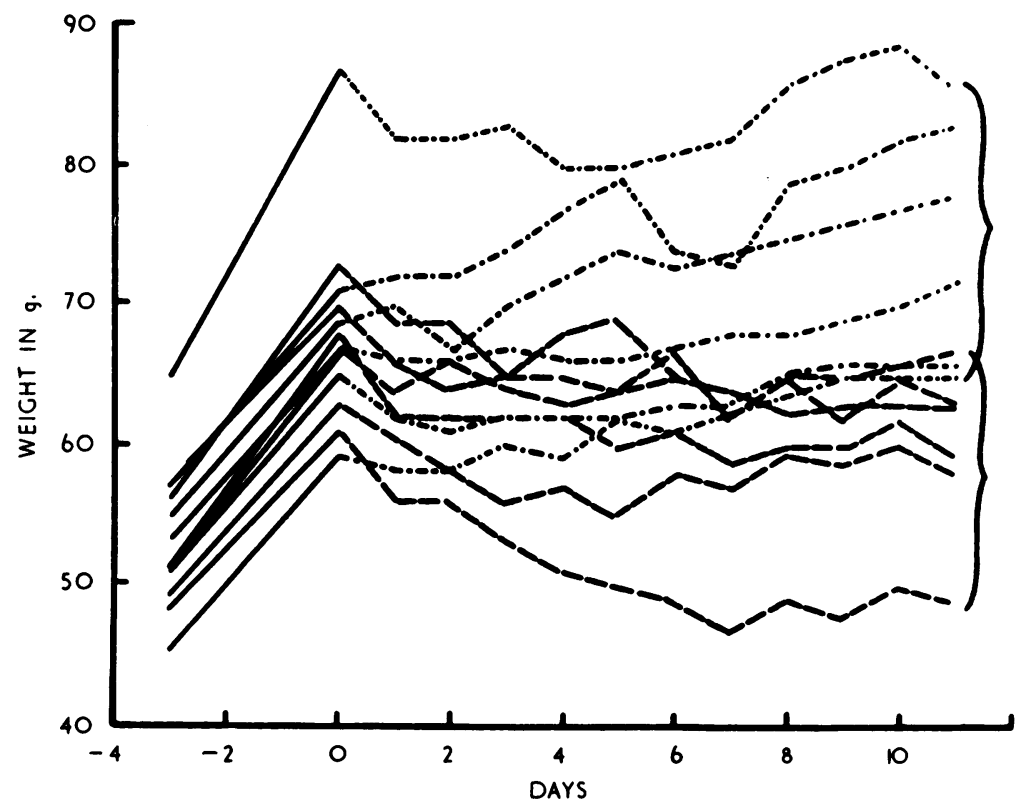

FIG. 4.-Growth curves of immature rats fed on the following: Minafen containing dextrimaltose instead of lactose + phenylalanine (Table 6, Group c), - - - - ; minafen and phenylalanine (Table 6, Group b), _ _ . Diets began on Day 0. 
It was concluded that minafen was improved by (1) changing the sugar to dextrimaltose, and (2) adding extra Cho, E, F and $\mathrm{B}_{2}$.

With the new preparation, rats remained lively, their fur remained sleek and only a trace of brown exudate formed. They developed fat pads and their genitalia developed normally. However, the A/B ratio still remained high and compared with rats fed on lofenalac they did not grow so well. It was unfortunate that the calorie intake could not be increased by force-feeding, since minafen was still not so acceptable to the rats feeding ad lib. as was lofenalac.

Experiment 6: Effect of adding 'nutromalt' to minafen. It was the opinion of the Nursing Staff that if 'nutromalt' (A. Wander Ltd.) was added to minafen it increased the palatability of the food and the infant thrived better. Nutromalt contains approximately 33\% maltose, $66 \%$ dextrin, a trace of protein, and a little salt; it provides 100 calories per $28 \mathrm{~g}$.

To each $100 \mathrm{~g}$. of synthetic food were added $25 \mathrm{~g}$. nutromalt. Groups of four and six immature rats received (a) $\mathbf{L}+\mathrm{Phe}$, and $(b) \mathbf{M}$ containing lactose instead of dextrimaltose + Phe $+F+B_{2}+$ Cho $+E$ (amounts as in Table 4) respectively, ad lib.

The rats did not eat significantly more than when nutromalt was not added, the mean daily intake per rat being 54 and 36 calories for the two groups respectively, nor were there any significant differences in their growth or appearance.

\section{Case Reports}

Effect of administering dietary supplements to child with the rash. D.D., a phenylketonuric girl aged 3 years, was placed on a low-phenylalanine diet when she was 5 months old. During the past year she had been difficult with her food and her plasma Phe level had been 8-13 mg./100 ml. (chromatographic method detecting $1 \mathrm{mg} . / 100 \mathrm{ml}$. plasma). In the two to three months before this admission her mother had made a great effort to keep her to her diet, but the child ate only a negligible amount of lofenalac and was in fact existing mainly on 'ribena', potato chips, an occasional apple and two 10-oz. loaves of 'kindercake E.A.' (Birkett and Bostock Ltd.) per week. A few days before admission she developed an erythematous rash on the perineum and then multiple well-defined, erythematous, scaly lesions on the trunk, back and arms. This was not a typical phenylketonuric rash, nor severe like that seen in patient D.B. At this time her plasma Phe level was $10 \mathrm{mg} . / 100 \mathrm{ml}$.

While continuing the same ill-balanced diet, she was given in succession: (1) $\alpha$-tocopheryl acetate $10 \mathrm{mg}$. t.d.s. for three days; (2) riboflavine $10 \mathrm{mg}$./day for four days; (3) choline $36.5 \mathrm{mg}$. t.d.s. for three days; and (4) $\alpha$-tocopheryl acetate $10 \mathrm{mg}$. t.d.s., + riboflavine $10 \mathrm{mg}$. daily, + choline $36.5 \mathrm{mg}$. t.d.s. daily, for 10 days.

During the administration of (1) and (2) there was little change in the rash; during (3) it seemed slightly reduced, though this was difficult to assess as it varied slightly in appearance from time to time in any case. One day after beginning (4) the rash had begun to go, within three days it had almost disappeared and by four days only a trace of one patch was left. In addition, the child was much brighter and happier. During the administration of (2) and (4) the serum phenylalanine level was $10 \mathrm{mg} . / 100 \mathrm{ml}$. The rash did not recur and after 10 days on (4) she was placed on a properly balanced low-phenylalanine diet in which she actually ate correct amounts of lofenalac. After seven days on the diet her serum phenylalanine was $4 \mathrm{mg} . / 100 \mathrm{ml}$. and the rash had not recurred.

Effect of feeding the modified preparation of minafen to a non-phenylketonuric child. Nitrogen balances (three-day periods) were performed as previously described (Clayton and Cotton, 1961) in a non-phenylketonuric baby who received National dried full-cream milk (ND), 'modified minafen'* and then lofenalac in succession. Phe 1\% (w/w) was added to both the synthetic foods. 'Modified minafen' contained (a) dextrimaltose instead of lactose, (b) the other constituents always present in minafen, and (c) extra amounts of vitamins as indicated by the experiments described, i.e. $35 \mu \mathrm{g}$. folic acid, $530 \mu \mathrm{g}$. riboflavine, $88 \mathrm{mg}$. choline, and $5.75 \mathrm{mg}$. $\alpha$-tocopherol per $100 \mathrm{~g}$. synthetic food.

Fig. 5 shows the weight chart of the child, and the times at which the balances were performed. The results of the balances are given in Table 7. The infant thrived, increased in weight and retained $1.8 \mathrm{~g}$. nitrogen daily while receiving 'modified minafen' and 5 drachms nutromalt. Though the percentage of dietary nitrogen retained was approximately the same on the three foods, the absolute amounts of nitrogen retained were greater with ND and lofenalac, being $+3 \cdot 1$ and $+2 \cdot 7 \mathrm{~g}$. per day respectively.

\section{Discussion}

The treatment of phenylketonuria with a lowphenylalanine diet has undoubtedly been successful, though difficulties have been encountered in the use of synthetic foods in young children (Hsia, Paine and Knox, 1957; Lewis, 1960). The investigations now reported draw attention to the need to consider all nutrients carefully when synthetic diets are being constructed, and they particularly emphasize the interdependence of various nutritional factors and the rapidity with which deficiencies can develop in the young.

Recently, increasing emphasis has been laid on the importance of the inhibition of enzymic processes by metabolites of phenylalanine. For example, Davison and Sandler (1958), and Tashian (1961) have demonstrated the inhibition of 5-hydroxytryptophan decarboxylase and glutamic acid decarboxylase respectively. It is, therefore, possible that bizarre dietary deficiencies might be produced in the presence of intakes considered adequate for normal infants.

\footnotetext{
* Kindly made by Trufood Ltd.
} 


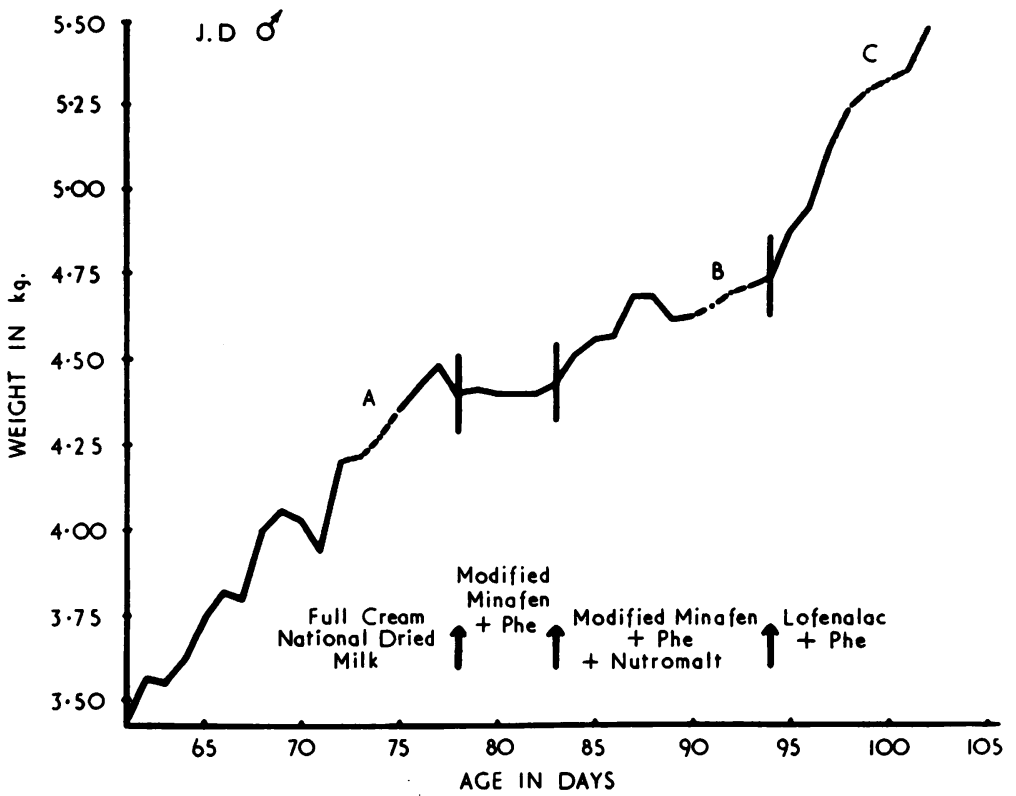

Fig. 5.-Growth curve of J.D. Balances were performed during periods A, B and C, and the intakes were as follows:

$\begin{array}{lccc} & \text { A } & \text { B } & \text { C } \\ \text { Nitrogen (g.) } & 5 \cdot 69 & 3 \cdot 18 & 4 \cdot 25 \\ \text { Fat (g.) } & 35 \cdot 0 & 48 \cdot 3 & 34 \cdot 4 \\ \text { Carbohydrate (g.) } & 71 \cdot 4 & 94 & 128 \\ \text { Calories } & 740 & 890 & 930\end{array}$

An important factor to be kept in mind when using a synthetic diet is the possibility of changes in the intestinal flora. Even the feeding of cows' milk as opposed to human milk leads to great differences (Douglas, 1951; Robinson, 1951). It is possible that some changes in intestinal flora may be harmful because they utilize essential nutrients or form toxic metabolites. De La Huerga and Popper (1951) and De La Huerga, György, Waldstein, Katz and
Popper (1953), have shown in man that by giving an antibiotic, dietary choline can be utilized to a greater extent because it is spared from bacterial degradation in the intestine.

Failure to gain weight and changes in the integrity of fur or skin are highly non-specific findings, always difficult to interpret and rarely permit the diagnosis of an isolated nutritional deficiency. Sidransky and Farber (1958) have stressed the com-

TABLE 7

NITROGEN BALANCES IN A BABY RECEIVING THREE DIFFERENT FOODS Each balance period was three days

\begin{tabular}{|c|c|c|c|c|c|c|c|c|c|c|c|}
\hline Balance & Diet & $\begin{array}{c}\text { Body } \\
\text { Weight } \\
\text { When } \\
\text { Balance } \\
\text { Began } \\
\text { (g.) }\end{array}$ & $\begin{array}{c}\text { Age } \\
\text { When } \\
\text { Balance } \\
\text { Began } \\
\text { (days) }\end{array}$ & $\begin{array}{c}\text { Mean } \\
\text { Daily } \\
\text { Calorie } \\
\text { Intake/ } \\
\text { kg. Body } \\
\text { Weight }\end{array}$ & $\begin{array}{c}\text { Nitrogen } \\
\text { Intake } \\
\text { During } \\
\underset{\text { Balance }}{\text { (g.) }}\end{array}$ & $\begin{array}{l}\text { Mean } \\
\text { Daily } \\
\text { Nitrogen } \\
\text { Intake/ } \\
\text { kg. Body } \\
\text { Weight } \\
\text { (g.) }\end{array}$ & $\begin{array}{c}\text { Urinary } \\
\text { Nitrogen } \\
\text { During } \\
\text { Balance } \\
\text { (g.) }\end{array}$ & $\begin{array}{c}\text { Faecal } \\
\text { Nitrogen } \\
\text { During } \\
\text { Balance } \\
\text { (g.) }\end{array}$ & $\begin{array}{c}\text { Nitrogen } \\
\text { Balance } \\
\text { per } \\
3 \underset{\text { Days }}{\text { (g.) }}\end{array}$ & $\begin{array}{c}\text { Nitrogen } \\
\text { Balance } \\
\text { per } \\
\text { Day } \\
\text { (g.) }\end{array}$ & $\begin{array}{c}\% \\
\text { Nitrogen } \\
\text { Retained } \\
\text { per } \\
\text { Day }\end{array}$ \\
\hline $\mathbf{A}$ & $\begin{array}{c}\text { National dried } \\
\text { full-cream } \\
\text { milk }\end{array}$ & $4 \cdot 0$ & 73 & 197 & $17 \cdot 07$ & $1 \cdot 33$ & $6 \cdot 72$ & 0.98 & $9 \cdot 37$ & $+3 \cdot 12$ & 55 \\
\hline B & $\begin{array}{l}\text { 'Modified } \\
\text { minafen' } \\
+ \text { Phe }\end{array}$ & $4 \cdot 4$ & 91 & 190 & $9 \cdot 54$ & 0.68 & $3 \cdot 17$ & 0.92 & $5 \cdot 45$ & $+1 \cdot 82$ & 57 \\
\hline C & $\begin{array}{c}\text { Lofenalac } \\
+ \text { Phe }\end{array}$ & $5 \cdot 1$ & 99 & 175 & $12 \cdot 75$ & 0.80 & 4.05 & 0.65 & 8.05 & +2.68 & 63 \\
\hline
\end{tabular}


plication of undernutrition itself when artificial diets are offered to rats. They also point out how the development of rough shaggy fur, weakness and lethargy are characteristic of several different amino acid deficiencies in rats. Similarly, the skin lesions seen in D.B. were similar to those reported with deficiency of essential fatty acids in infants (Hansen, Haggard, Boelsche, Adam and Wiese, 1958), but D.B. was receiving essential fatty acids from the arachis oil in minafen.

For optimum growth, a diet must provide each essential amino acid in the quantity required by the particular animal, and Hartsook and Mitchell (1956) have shown that this varies with age. The administration of excessive amounts of individual amino acids may indeed be harmful (Harper, 1958; Sauberlich, 1961) and Holt and Snyderman (1956) demonstrated the loss of weight in infancy when excess lysine was administered. There is also evidence that amino acid imbalance may lead to more severe vitamin deficiencies (DeBey, Snell and Baumann, 1952). Deficiencies of many essential amino acids produce a number of similar changes such as retardation of growth, diminished survival and changes in the liver (Sidransky and Baba, 1960). Increasing the amounts of tyrosine and tryptophan in minafen did not lead to any changes in the rats.

Ideally, dietary investigations should be performed in the human subject, though this is rarely practical, especially in infants; but great caution must always be exercised in applying the results of animal experiments to man.

Satisfactory synthetic diets have frequently been constructed for rats (Nasset, 1956; Hepburn, Calhoun and Bradley, 1960; Sidransky and Baba, 1960) and man, including infants (Snyderman, Holt and Boyer, 1960). The diets differ from minafen in providing much greater amounts of riboflavine, tocopherols and choline.

The investigations in the rats and the observations on the second patient point to the importance of choline, though direct evidence of disease in man due to choline deficiency is lacking. However, it has been strongly implicated as of importance in the aetiology of cirrhosis in chronic alcoholism (Hartroft, Lucas and Best, 1954). The principal test animal for the study of choline has been the rat, and deficiency, especially in weanling rats, leads to the development of fatty livers and haemorrhagic degeneration of the kidneys (Griffith, 1940; Hartroft, 1950), though these changes take some time to develop.

Choline is a fairly stable compound that functions as a methyl donor in intermediary metabolism and can be synthesized in the body from various com- pounds such as methionine (Schaefer and Knowles, 1951; Arnstein and Neuberger, 1953). It was shown by Du Vigneaud, Ressler and Rachele (1950) and Du Vigneaud, Ressler, Rachele, Reyniers and Luckey (1951) that the rat can synthesize the methyl groups found in choline or methionine provided that the diet is otherwise complete, and this is independent of the intestinal flora. Arnstein and Neuberger (1953) indicated that cobalamine played an important role in this process.

The toddler who developed the rash was receiving a grossly ill-balanced diet since kindercake E.A., her main food, contained only a trace of methionine and no choline. She would have been receiving only a small amount of choline from chipped potatoes. Engel (1943) gives the content of choline in Irish potatoes as $1.06 \mathrm{mg}$. $/ \mathrm{g}$.

It is of interest, too, that in milk choline is present in the aqueous layer and not in the cream (Kahane and Lévy, 1945), so that the choline intake of D.B. would still have been poor even when she received a large supplement of double cream in addition to minafen. On giving her cows' milk entirely her choline intake would have risen, but so would the intake of many other things, including phenylalanine.

The cause of the adrenal hypertrophy has not been fully elucidated. It is known that starvation leads to hypertrophy of the adrenal cortex (Mulinos and Pomerantz, 1941), though chronic malnutrition causes atrophy (Uehlinger, 1955). Changes in the structure and function of the adrenal of the rat have been demonstrated in deficiencies of pantothenic acid, riboflavine and thiamine (for a review see Morgan, 1951). Increasing the pantothenic acid, folic acid or riboflavine in minafen did not change the adrenal/body weight ratio.

Deficiency of riboflavine in rats is characterized by a reduced rate of growth and thinning of the fur and the adrenals are often congested with enlargement of the zona reticularis (Deane and McKibbin, 1946). In man, the deficiency leads to a sore tongue, angular stomatitis and seborrhoeic dermatitis of the nose and scrotum (Pollack, 1956). In weanling rats the tissue concentration of riboflavine falls rapidly if none is given in the diet, and the needs of the growing rat per gramme are three times those of the mature animal (Bessey, Lowry, Davis and Dorn, 1958). Since the addition of extra riboflavine to minafen improved the diet for young rats, it seems reasonable to assume that this might be beneficial to infants, especially as the synthetic diet of Snyderman et al. (1960), for infants, provides $2.0 \mathrm{mg}$. riboflavine daily.

Though vitamin $\mathrm{E}$ is widely distributed in animals 
and plants its exact role in the living cell has not been conclusively established. It probably acts as an intracellular antioxidant so preventing the oxidation of substances such as unsaturated fats, vitamin A and ascorbic acid. It is a component of the cytochrome-C reductase portion of the terminal respiratory chain, and it is probably important in the metabolism of nucleic acids (Vasington, Reichard and Nason, 1960). Though vitamin E deficiency produces profound effects on the reproductive system, musculature and body fat of animals, there is little direct evidence to indicate that it is essential for adult men. However, using haemolysis of the red blood cells by hydrogen peroxide as a test of vitamin $\mathrm{E}$ deficiency, low levels have been demonstrated in the newborn infant, and the speedy correction of this by breast milk, but not by skimmed cows' milk has been shown (Wright, Filer and Mason, 1951; Gordon and Nitowsky, 1956). There is thus good reason to make sure that an adequate amount is present in minafen, and the experiments in young rats indicate that the amount should be raised.

The relation between choline and vitamin $\mathrm{E}$ plus riboflavine in the second patient, D.D., is not clear, though there is no doubt that in some way the latter two acted in a permissive way for choline. The parts played by $(a)$ inhibition of enzymes by high serum phenylalanine and its metabolites, $(b)$ possible changes in intestinal flora, and $(c)$ other unknown deficiencies with such a restricted diet, cannot be assessed, but may well have contributed to this bizarre finding.

In 1927, Mitchell showed that if $60 \%$ of the diet of young rats was lactose they had varying degrees of diarrhoea and corresponding retardation of growth with the maximum weight gain being about half the normal. If the high lactose diet was continued, Whittier, Cary and Ellis (1935) found they began to grow well after three weeks and eventually nearly overtook the sucrose-fed rats, though the latter always had more fat in their bodies. No workers have suggested that the feeding of lactose caused the animals to become moribund. This intolerance of lactose has sometimes been observed by Professor A. A. Moncrieff in infants receiving artificial foods.

The greater retention of nitrogen by J.D. while receiving ND or lofenalac compared with 'modified minafen' + Phe is presumably a reflection of the greater nitrogen intake provided by the former foods, the nitrogen content of minafen on direct analysis being somewhat lower than expected.

The infant J.D. failed to gain on 'modified minafen' + Phe until nutromalt was added to the feeds. Since the addition of nutromalt only increased the intake of calories by 60 per day, it seems unlikely that it could account for the increased growth rate, though it is possible that the change in the ratio of calories coming from hydrolysate, fat and carbohydrate resulted in greater efficiency of caloric release from 'modified minafen'. It seems more likely that the initial failure to gain weight was due to an inability to adapt immediately to the synthetic diet after ND, and this interim period would perhaps have been encountered even if nutromalt had been added initially or if lofenalac had followed immediately on a milk diet.

As a result of the investigations, minafen was modified by the addition of extra riboflavine, choline, $\alpha$-tocopherol and folic acid, and the substitution of lactose by dextrimaltose. This 'modified minafen' + Phe was shown to be a suitable food for an infant, but attention is drawn to the fact that it has a somewhat lower nitrogen content than National dried full-cream milk and lofenalac.

Supplementation of 'modified minafen' with milk or another phenylalanine-containing food in sufficient amount would, of course, still be necessary in a phenylketonuric infant.

We are grateful to Professor A. A. Moncrieff for his advice and encouragement. We thank him and Dr. A. P. Norman for allowing us to investigate their patients. We thank Miss J. Kendall for her technical assistance. We also received invaluable help in many ways from Miss D. J. W. Austin, Mr. A. Allnutt, Mrs. C. King, and members of the Nursing Staff. Mr. J. V. Hyde of Trufood Ltd., and Dr. H. N. H. Genese, and Dr. L. K. Bachmann, of Mead Johnson Ltd., gave us every assistance by providing many individual compounds used in the synthetic foods. We are grateful to the Research Committee of The Hospital for Sick Children for financial assistance with this investigation.

\section{REFERENCES}

Arnstein, H. R. V. and Neuberger, A. (1953). The effect of cobalamin on the quantitative utilization of serine, glycine and formate for the synthesis of choline and methyl groups of methionine. Biochem. J., 55, 259.

Bessey, O. A., Lowry, O. H., Davis, E. B. and Dorn, J. L. (1958) The riboflavin economy of the rat. J. Nutr., 64, 185 .

Brimblecombe, F. S. W., Blainey, J. D., Stoneman, M. E. R. and Wood, B. S. B. (1961). Dietary and biochemical control of Wood, B. S. B. (1961). Dietary and
phenylketonuria. Brit. med. J., 2, 793.

Clayton, B. E. and Cotton, D. A. (1961). Study of malabsorption after resection of the entire jejunum and the proximal half of the ileum. Gut, 2, 18.

Davison, A. N. and Sandler, M. (1958). Inhibition of 5-hydroxytryptophan decarboxylase by phenylalanine metabolites. Nature (Lond.), 181, 186.

DeBey, H. J., Snell, E. E. and Baumann, C. A. (1952). Studies on the interrelationship between methionine and vitamin $\mathbf{B}_{6}$. J. Nutr., 46, 203.

De La Huerga, J., György, P., Waldstein, S., Katz, R. and Popper, H. (1953). The effects of antimicrobial agents upon choline degradation in the intestinal tract. J. clin. Invest., 32, 1117. - and Popper, H. (1951). Urinary excretion of choline metabolites following choline administration in normals and patients with hepatobiliary diseases. ibid., 30, 463.

Deane, H. W. and McKibbin, J. M. (1946). The chemical cytology of the rat's adrenal cortex in pantothenic acid deficiency. Endocrinology, 38, 385. 
Douglas, J. W. B. (1951). Health and survival of infants in different social classes. A National survey. Lancet, 2, 440.

Du Vigneaud, V., Ressler, C. and Rachele, J. R. (1950). The biological synthesis of 'Iabile methyl groups'. Science, 112, 267. , - Reyniers, J. A. and Luckey, T. D. (1951). The synthesis of 'biologically labile' methyl groups in the germ-free rat. J. Nutr., 45, 361.

Engel, R. W. (1943). The choline content of animal and plant products. ibid., $25,441$.

Gordon, H. H. and Nitowsky, H. M. (1956). In Symposium on the role of some of the newer vitamins in human metabolism and nutrition, n. 83. Nutrition Symposium series No. 12. National Vitamin Foundation, New York.

Griffith, W. H. (1940). Choline metabolism. iv. The relation of the age, weight and sex of young rats to the occurrence of hemorrhagic degeneration on a low choline diet. $J$. Nutr. $19,437$.

Hansen, A. E. Haggard, M. E., Boelsche, A. N., Adam, D. J. D. and Wiese, H. F. (1958). Essential fatty acids in infant nutrition. III. Clinical manifestation of linoleic acid deficiency. ibid. 66, 565

Harper, A. E. (1958). Balance and imbalance of amino acids. Ann. N.Y. Acad. Sci., 69, 1025.

Hartroft, W. S. (1950). Accumulation of fat in liver cells and in lipodiastaemata preceding experimental dietary cirrhosis. Anat. Rec., 106, 61.

, Lucas, C. C. and Best, C. H. (1954). Choline. X. Effects of Deficiency $F$. Man. In The Vitamins, ed. W. H. Sebrell and R. S. Harris, vol. 2, p. 104 . Academic Press, New York.

Hartsook, E. W. and Mitchell, H. H. (1956). The effect of age on the protein and methionine requirements of the rat. J. Nutr. $60,173$.

Hepburn, F. N., Calhoun, W. K. and Bradley, W. B. (1960). A growth response of rats to glutamic acid when fed an amino acid diet. ibid., 72, 163 .

Holt, L. E., Jr. and Snyderman, S. E. (1956). The amino acid requirements of children. In Some Aspects of Amino Acid Supplementation, ed. W. H. Cole, p. 60 . Rutgers University Press, New Brunswick, New Jersey.

Hsia, D. Y. Y., Paine, R. S. and Knox, W. E. (1957). Nutritional and chenical pitfalls in the treatment of phenylketonurics by means of low-phenylalanine diets. A.M.A. J. Dis. Child. 94, 495 .

Kahane, E. and Lévy, J. (1945). Biochimie de la choline et de ses dérivés. XIV: Substances choliniques de l'intestin. Historiques et généralités. Bull. Soc. Chim. biol. (Paris), 27, 167.

Lewis, I. C. (1960). An unusual case of phenylketonuria. Med. J. Aust., $2,811$.

Mitchell, H. S. (1927). Comparative physiological values of five carbohydrates, based on growth and fecal analysis. Amer. J. Physiol., 79, 537.
Moncrieff, A. A. and Wilkinson, R. H. (1961). Further experiences in the treatment of phenylketonuria. Brit. med.J., 1, 763

Morgan, A. F. (1951). The effect of vitamin deficiencies on adrenocortical function. Vitam. and Horm., 9, 161

Mulinos, M. G. and Pomerantz, L. (1941). Hormonal influences on the weight of the adrenal in inanition. Amer. J. Physiol., $132,368$.

Nasset, E. S. (1956). Essential amino acids and nitrogen balance. In Some Aspects of Amino Acid Supplementation, ed. W. H. Cole, p. 3. Rutgers University Press, New Brunswick. New Jersey.

Pollack. H. (1956). Studies on nutrition in the Far East. III Clinical indicator signs of nutritional insufficiencies before and after enrichment of rice with synthetic vitamins. Metabolism, 5,231 .

Robinson, M. (1951). Infant morbidity and mortality. A study of 3266 infants. Lancet, 1, 788.

Sauberlich, H. E. (1961). Growth of rats fed protein-free diets supplemented with purified amino-acid mixtures. J. Nutr., 74, 298.

Schaefer, A. E. and Knowles, J. L. (1951). Influence of vitamin $B_{12}$ and folacin on the synthesis of choline and methionine by the rat. Proc. Soc. exp. Biol. (N.Y.), 77, 655.

Sidransky, H. and Baba, T. (1960). Chemical pathology of acute amino acid deficiencies. III: Morphologic and biochemical changes in young rats fed valine- or lysine-devoid diets. J. Nutr., $70,463$.

- and Farber, E. (1958). Chemical pathology of acute amino acid deficiencies. I. Morphologic changes in immature rats fed threonine- methionine-, or histidine-devoid diets. A.M.A. Arch. Path., 66, 119.

Snyderman, S. E., Holt, L. E., Jr. and Boyer, A. (1960). Amino acid reference patterns: a comparison of the pattern of human milk with the FAO pattern in human nutrition. J. Nutr., 72, 404.

Tashian, R. E. (1961). Inhibition of brain glutamic acid decarboxylase by phenylalanine, valine, and leucine derivatives: a suggestion concerning the etiology of the neurological defect in phenylketonuria and branched-chain ketonuria. Metabolism, 10, 393.

Uehlinger, E. (1955). The adrenal and famine. Ciba Foundation Colloquia on Endocrinology, 8, 92. The Human Adrenal Cortex, ed. G. E. W. Wolstenholme and M. P. Cameron. Churchill, London.

Vasington, F. D., Reichard, S. M. and Nason, A. (1960). Biochemistry of vitamin E. Vitam. and Horm., 18, 43.

Whittier, E. O., Cary, C. A. and Ellis, N. R. (1935). The effect of lactose on growth and longevity. J. Nutr., 9, 521 .

Wright, S. W., Filer, L. J., Jr. and Mason, K. E. (1951). Vitamin E blood levels in premature and full term infants. Pediatrics, 7,386 . 